Journal of Engineering and Applied Sciences 14 (Special Issue 3): 6006-6013, 2019

ISSN: 1816-949X

(C) Medwell Journals, 2019

\title{
Performance of Backflow Corrugated Solar Air Collector in the Climatic Conditions of Middle Iraq
}

\author{
${ }^{1,2}$ Ali Mohammed Hayder, ${ }^{1}$ Azwan Bin Sapit, ${ }^{2}$ Qahtan Adnan Abed and \\ ${ }_{1,2}^{2}$ Mohammed Saad Abbas \\ ${ }^{1}$ Faculty of Mechanical and Manufacturing Engineering, University Tun Hussein Onn Malaysia, \\ Batu Pahat, Johor, Malaysia \\ ${ }^{2}$ Al-Furat Al-Awsat Technical University, Al Najaf, Iraq \\ ali.m858@yahoo.com
}

\begin{abstract}
In this study, a corrugated solar air collector has been investigated experimentally to enhance the performance of conventional solar air collectors. Sets of experiments have been executed according to the standard ASHRAE tests, under climatic conditions in Najaf city in Iraq. The effect of the difference in air mass flow rate on thermal performance was studied for a corrugated solar air collector. The results reveal that the outlet air temperature decreases with increasing air mass flow rate which leads an increase in the thermal efficiency value as a result of low thermal losses to the atmosphere. The density of solar radiation and the appropriate climatic conditions of Najaf city makes the use of solar air collectors appropriate for reducing the use of fossil fuels and electricity consumption in many applications.
\end{abstract}

Key words: Solar air collector, corrugated plate surface, air mass flow rate, thermal efficiency, performance evaluation, temperature

\section{INTRODUCTION}

Iraq is a country in Western Asia, located in the Northeast of the Arabian Peninsula. It is bounded by Saudi Arabia, Kuwait, Iran, Turkey, Syria and Jordan. The total area of Iraq is $437.367 \mathrm{~km}^{2}$ of which $950 \mathrm{~km}^{2}$ are water areas. The South of Iraq mostly has pleasant weather conditions, except for the possibility of sandstorms which can sometimes occur due to the presence of desert in the area. Southern Iraq is one of the regions with the highest amount of solar radiation in the world (Al-Douri and Abed, 2016). Iraq has long faced many challenges, most notably a lack of electricity. Therefore, the exploitation of renewable energy resources represents a significant means to reduce this problem.

Solar energy has major possibilities for many applications, especially, low-temperature applications such as drying agricultural crops (Chemkhi et al., 2004), heating of buildings (Hashe, 2017) and the construction industry (Heydari and Mesgarpour, 2018). Therefore, solar energy represents the best choice for such applications due to the fact that it uses hot air directly without the need for an additional heat exchanger at the thermal systems (Karim and Hawlader, 2006). In solar thermal systems, the function of a solar energy collector is to absorb solar irradiance and convert it into thermal energy as latent thermal energy or sensible thermal energy. After, it transports the thermal energy to the working fluid (Saxena et al., 2015). Conventional flat plate solar collectors are considered the most commonly used type of collectors in other solar heating system applications, despite the fact that the response period of flat plate solar collectors is very long when used for greenhouse heating (Kiyan et al., 2013). Solar air collectors offer a favorable heating technology for industrial operations and heating of buildings due to their low cost and simplicity.

In general, the performance evaluation of a solar air collector directly affects five critical parameters outdoor and absorber surface temperatures, air volume, air flow, wind velocity and the intensity of solar irradiance. Hence, thermal efficiency is calculated as a baseline indicator to evaluate the performance of a solar air collector depending on those parameters (Yang et al., 2012). Recently, many researchers have focused on the effect study of those five parameters to enhance the thermal performance of solar systems without using a thermal storage unit. Improvements to thermal efficiency have been carried out via. increasing the area of the heat transfer surface (Yeh and Lin, 1996). However, when using fins in the air flow channel, turbulence was increased

Correponding Author: Ali Mohammed Hayder, Faculty of Mechanical and Manufacturing Engineering, University Tun Hussein Onn Malaysia, Batu Pahat, Johor, Malaysia, ali.m858@yahoo.com 


\section{J. Eng. Applied Sci., 14 (Special Issue 3): 6006-6013, 2019}

(Mahmood et al., 2015). Nonetheless, the turbulence of air flow in the impinging jet improved the heat transfer rate in the flat plate collector (Rajaseenivasan et al., 2017). Wind velocity is a very effective function to calculate the heat transfer coefficient (Karwa and Srivastava, 2013). Furthermore, the intensity of solar irradiance is considered the main parameter affecting the performance of a solar collector. This is because it depends on the absorption of the collector surface and the transmittance of the glass cover (Arunachalam and Edwin, 2017).

An experimental study of an unglazed solar air collector with a perforated absorber flat plate surface for heating a building in climatic conditions in Western Iraq was carried out by Al-Damook and Khalil (2017). The researchers have found that the maximum difference of temperature is 6 and $17^{\circ} \mathrm{C}$ on cloudy and sunny days, respectively, at solar noon period.

Numerical investigations were performed by Mohammad (2017) for the performance evaluation of the solar evacuated tube collector for the space heating building. The studies were conducted under the climatic conditions of the city of Baghdad in Iraq for 5 months from the beginning of November to the end of March. The results of this study proved that a maximum thermal efficiency of $35.75 \%$ was obtained in December.

Experimental investigations were executed by Aboghrara et al. (2017) to study the influence of jet impingement on the performance of corrugated plate compared with a flat plate for the solar air collectors. The researcher demonstrated that the corrugated plate gives an average thermal efficiency of $14 \%$ with a $3^{\circ} \mathrm{C}$ increase in temperature higher than the flat plate.

An experimental study was also published by Li et al. (2017) to assess the performance of a solar air collector using four various absorber surface shapes flat plate surface, corrugated surface, protrusion surface and corrugated surface with protrusion. The researcher indicated that the best heat transfer was obtained when using the corrugated plate as an absorber surface.

An experimental performance analysis of a solar air collector was also conducted by Hassan and Abo-Elfadl, (2018) using four various absorber surfaces shapes: flat plate, pin finned, corrugated finned and corrugated perforated finned. The results revealed that the maximum thermal efficiency was obtained of the corrugated perforated finned surface.

Karim and Hawlader (2006) carried out an experimental and theoretical comparison study of the performance of three types of solar air collector: corrugated collector, flat plate with single pass collector and flat plate with double pass collector. The researchers observed that the thermal efficiency for the corrugated collector increased by 10 and $15 \%$, respectively, compared with the single pass collector and double pass collector. Moreover, the corrugated collector was more structurally stable than the other used species.

A cross-corrugated solar air collector model was suggested by Lin and Liu (2006). The model consists of wavy plates from absorbing and bottom sides. It was found that the thermal performance for the proposed model was very high compared to the flat plate collector. In addition, the use of wavy plates led to an improvement in the thermal efficiencies of the solar air heater collector.

An experimental analysis for both corrugated and flat plate of the solar air collector was carried out by Lakshmi et al. (2017). The results indicated that the obtained efficiency of the corrugated plate increased by $5.7 \%$ compared to the flat plate of the solar air collector. Furthermore, the outlet air temperature of the corrugated plate was higher than the flat plate.

A article was published by Kabeel et al. (2016) to compare the performance of the corrugated and flat plate of the solar air collector. The researcher has demonstrated that the convection heat transfer coefficient of the corrugated plate was more than the flat plate. Consequently, the daily efficiency of the corrugated plate was more than the flat plate by $21.3 \%$ at the same air mass flow value rate: $0.062 \mathrm{~kg} / \mathrm{sec}$.

A numerical simulation was carried out by Karim et al. (2014) to study the influence of some parameters on evaluating the performance of the corrugated solar air collector with a single and double air flow channel. The results of this numerical simulation indicate that the solar irradiance, wind speed, air mass flow rate and input air temperature had the same influence on the performance of a single and double air flow channel. In addition, the impact of the collector length varied greatly between the single and double air flow channel due to the different air flows inside the channel.

An experimental and theoretical study was performed by El-Sebaii et al. (2011) to compare the performance of a double pass corrugated solar air collector and a double pass finned solar air collector. The researcher noted that the maximum thermal efficiency of the corrugated solar air collector increased by $17.4 \%$ more than the finned solar air collector. Moreover, the outlet air temperature of the corrugated solar air collector increased by $2.1-9.7 \%$ more than the finned solar air collector.

In summary, many interesting results indicating the potential of corrugated plate as an absorber surface for solar irradiance of solar air heating systems have been reported. Therefore, the present study suggests an experimental investigation to evaluate the performance fo 
a corrugated solar air collector which was fabricated using locally available materials and tested under climatic conditions in the Najaf city of Iraq.

Thermal analysis of the solar air collector: The solar air collector in the present research consists of a corrugated absorber plate surface covered on its top side by a transparent glass cover. The air flows across a narrow channel between the corrugated absorber surface and the isolated collector bottom. Figure 1 shows the thermal analysis of the components of the corrugated solar air collector. In this study, the governing equations of the corrugated solar air collector are presented. The convection heat transfer coefficient between the absorber plate surface and the transparent glass cover is given by the following Eq. 1-5 (Duffie and Beckman, 2013; Kalogirou, 2014):

$$
\begin{gathered}
\mathrm{h}_{\mathrm{conv}(p-\mathrm{g})}=\frac{\mathrm{N}_{\mathrm{u}(\mathrm{p}-\mathrm{g})} \mathrm{k}_{\mathrm{air}}}{1} \\
\mathrm{~N}_{\mathrm{u}(\mathrm{p}-\mathrm{g})}=0.1673\left(\mathrm{R}_{\mathrm{a}} \cos \beta\right)^{0.2917} \\
\mathrm{R}_{\mathrm{a}}=\frac{\mathrm{g} \cdot \beta^{\prime} \cdot \mathrm{P}_{\mathrm{r}}}{v^{2}}\left[\mathrm{~T}_{\mathrm{p}}-\mathrm{T}_{\mathrm{g}}\right] 1^{3} \\
\beta^{\prime}=\frac{1}{\mathrm{~T}_{\mathrm{m}}} \\
\mathrm{T}_{\mathrm{m}}=\frac{\mathrm{T}_{\mathrm{p}}+\mathrm{T}_{\mathrm{g}}}{2}
\end{gathered}
$$

The radiation heat transfer coefficient between the absorber plate surface and the transparent glass cover is given by the following Eq. 6 (Duffie and Beckman, 2013; Kalogirou, 2014):

$$
\mathrm{h}_{\mathrm{rad}(\mathrm{p}-\mathrm{g})}=\frac{\sigma\left[\mathrm{T}_{\mathrm{p}}+\mathrm{T}_{\mathrm{g}}\right]\left[\mathrm{T}_{\mathrm{p}}^{2}+\mathrm{T}_{\mathrm{g}}^{2}\right]}{\frac{1}{\varepsilon_{\mathrm{p}}}+\frac{1}{\varepsilon_{\mathrm{g}}}-1}
$$

The convection heat transfer coefficient between the transparent glass cover and the ambient is given by the following Eq. 7 (Duffie and Beckman, 2013; Kalogirou, 2014):

$$
\mathrm{h}_{\mathrm{conv}(\mathrm{g}-\mathrm{amb})}=\mathrm{h}_{\mathrm{w}}=\frac{8.6\left(\mathrm{~W}_{\mathrm{V}}\right)^{0.6}}{\left(\mathrm{~L}_{\mathrm{c}}\right)^{0.4}}
$$

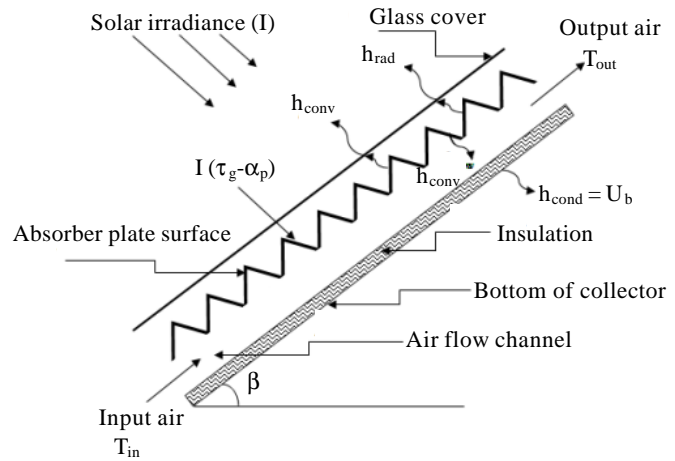

Fig. 1: Thermal analysis of the corrugated solar air collector

The radiation heat transfer coefficient between the transparent glass cover and the ambient is given by the following Eq. 8 (Duffie and Beckman, 2013; Kalogirou, 2014):

$$
\mathrm{h}_{\mathrm{rad}(\mathrm{g}-\mathrm{amb})}=\varepsilon_{\mathrm{g}} \sigma\left(\mathrm{T}_{\mathrm{g}}+\mathrm{T}_{\mathrm{amb}}\right)\left(\mathrm{T}_{\mathrm{g}}^{2}+\mathrm{T}_{\text {amb }}^{2}\right)
$$

The heat transfer coefficient between the air flow channel and the absorber plate surface is given by the following Eq. 9 and 10 (Duffie and Beckman, 2013; Kalogirou, 2014):

$$
\begin{gathered}
\mathrm{h}_{\text {conv(p-air) }}=\frac{\mathrm{N}_{\mathrm{u}(\mathrm{p} \text {-air) }} \cdot \mathrm{k}_{\mathrm{air}}}{\mathrm{H}_{\mathrm{D}}} \\
\mathrm{H}_{\mathrm{D}}=4\left(\frac{\mathrm{W}_{\mathrm{c}} \mathrm{H}_{\mathrm{ch}}}{2 \mathrm{~W}_{\mathrm{c}}}\right)=2 \mathrm{H}_{\mathrm{ch}}
\end{gathered}
$$

The Nusselt number for the turbulent flow inside the air flow channel at $3000 \leq \mathrm{R}_{e} \leq 50000$ is given by the following Eq. 11 and 12 (Duffie and Beckman, 2013; Kalogirou, 2014):

$$
\begin{aligned}
N_{u(p-\text { air })} & =0.0743\left(R_{e}\right)^{0.76} \\
R_{e} & =\frac{\rho V_{\text {air }} H_{D}}{\mu}
\end{aligned}
$$

When a falls in solar radiation on the solar collector, the absorber plate surface absorbs most of it and delivers it to the working fluid and converts it as useful energy. However, a part of this energy is lost as in all thermal systems by different means of heat transfer. Therefore, the following equation gives the sum energy losses from the solar air collector (Duffie and Beckman, 2013; Kalogirou, 2014): 


$$
\mathrm{U}_{\mathrm{L}}=\mathrm{U}_{\mathrm{t}}+\mathrm{U}_{\mathrm{b}}+\mathrm{U}_{\mathrm{e}}
$$

where, $U_{L}, U_{b} U_{b}$ and $U_{e}$ are the overall, top, bottom and edges heat loss coefficient, respectively, therefore:

$$
\begin{gathered}
\mathrm{U}_{\mathrm{t}}=\left[\frac{1}{\left(\mathrm{~h}_{\mathrm{conv}(\mathrm{p} \cdot \mathrm{g})}+\mathrm{h}_{\mathrm{rad}(\mathrm{p}-\mathrm{g})}\right)}+\frac{1}{\left(\mathrm{~h}_{\mathrm{w}}+\mathrm{h}_{\mathrm{rad}(\mathrm{g} \cdot \mathrm{amb})}\right)}\right] \\
\mathrm{U}_{\mathrm{b}}=\frac{\mathrm{k}_{\mathrm{g} \cdot \mathrm{w}}}{\mathrm{t}_{\mathrm{g} \cdot \mathrm{w}}} \\
\mathrm{U}_{\mathrm{e}}=\frac{\mathrm{k}_{\mathrm{g} \cdot \mathrm{w}} \mathrm{p}_{\mathrm{c}} \mathrm{H}_{\mathrm{c}}}{\mathrm{t}_{\mathrm{g} \cdot \mathrm{w}} \mathrm{A}_{\mathrm{c}}}
\end{gathered}
$$

The thermal efficiency of the solar air collector is defined as the ratio of the obtained useful thermal energy from solar irradiance to the gross radiated thermal energy onto the collector surface (Duffie and Beckman, 2013; Kalogirou, 2014):

$$
\eta_{\text {th }}=\frac{Q_{u}}{I_{T} \cdot A_{c}}
$$

The useful energy equation is the only governing Eq. 18 and 19 for the working fluid and is calculated by measuring an air mass flow rate and the temperature difference between the inlet and outlet for the working fluid from the collector (Duffie and Beckman, 2013; Kalogirou, 2014):

$$
\begin{gathered}
\mathrm{Q}_{\mathrm{u}}=\dot{\mathrm{m}}_{\mathrm{air}} \mathrm{C}_{\mathrm{p}}\left(\mathrm{T}_{\text {out }}-\mathrm{T}_{\text {in }}\right) \\
\dot{\mathrm{m}}_{\mathrm{arr}}=\rho \mathrm{v}_{\mathrm{air}} \mathrm{A}_{\text {ext }}
\end{gathered}
$$

\section{MATERIALS AND METHODS}

Experimental setup: The main aim of the present study is to investigate the thermal performance evaluation of a solar air collector. The system consisted of two units, namely, the collector and the air processing unit. The collector unit involved a single corrugated plate surface which was made from a mild aluminum plate with a $0.8 \mathrm{~mm}$ thickness. The plate was black in order to increase the absorptivity of the fallen solar irradiance and reduce thermal reflectivity. The solar air collector was insulated using glass wool on the bottom and lateral sides with a $20 \mathrm{~mm}$ thickness in order to reduce thermal losses to the atmosphere. Moreover, the top side of the solar air collector was covered by a transparent glass plate to

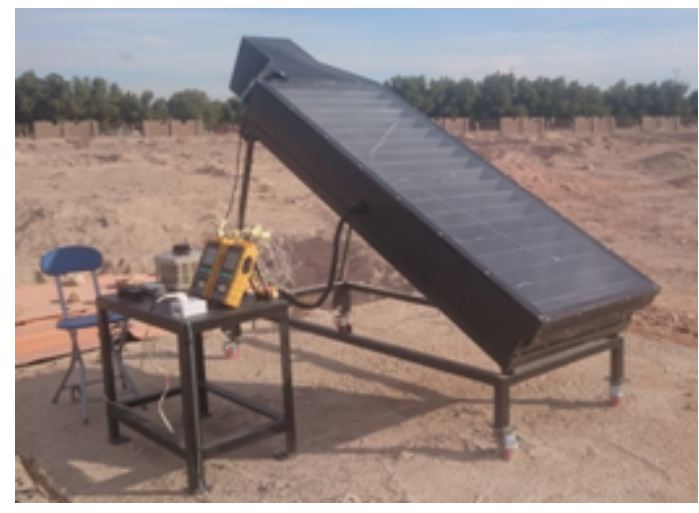

Fig. 2: Photograph of the experimental setup for corrugated solar air collector

reduce the heat convection losses with a $4 \mathrm{~mm}$ thickness and an area of $1.8 \times 0.7 \mathrm{~m}^{2}$. Plywood with a $16 \mathrm{~mm}$ thickness was used for the fabrication of the solar air collector. Furthermore, the dimensions of the air flow channel for the solar air collector were $1.8 \mathrm{~m}$ in length, $0.7 \mathrm{~m}$ in width and $0.07 \mathrm{~m}$ in height. The air processing unit consisted of a fan with a speed controller. This fan was a variable velocity axial flow type. The axial fan was placed in the exit section of the solar air collector where it forced air to pass through the air flow channel under the absorbing surface.

The solar air collector was fabricated and tested at the Engineering Technical College of Al-Najaf, Al-Furat Al-Awsat Technical University located in the center of Iraq $31^{\circ} 57^{\prime} \mathrm{N}$ and $44^{\circ} 15^{\prime} \mathrm{E}$ (Al-Douri and Abed, 2016). The solar air collector was installed outdoors at a tilt angle of facing southerly direction in order to receive maximum solar radiation. The solar air collector was placed on frames with wheels for easier transport. Moreover, the frames were designed, so that, the tilt angle can be changed to specify the position and direction of the solar air collector as shown in Fig. 2. The experimental tests were repeated for various air mass flow rates: $0.023,0.034$ and $0.045 \mathrm{~kg} / \mathrm{sec}$ on forced convection. The variable parameters were measured and recorded at a time interval of every $10 \mathrm{~min}$. The variable parameters which involved $T_{\text {amb }}, T_{\text {out }}, T_{g}, T_{p}, I$ and $W_{v}$ were discussed every $1 \mathrm{~h}$ for an average of six actual reading values. The experiments were carried out for 3 days: 9-11 th January 2018 from 10 AM to 4 PM for all days.

The variations in air temperatures were measured in the current experimental tests by using K-type thermocouples which were distributed in different places of the solar air collector. In addition, all K-type thermocouples were fitted in a data logger and all the data was registered automatically. The air speed was monitored 
using a standard device AM-4826 anemometer. A standard device Tenmars TM-207 pyranometer was used to measure the intensity of solar irradiance falling on the absorber surface. Furthermore, the weather station device Vantage Pro2' was used to measure and give realistic readings for all climatic conditions in the experimental area such as solar irradiance, wind speed, humidity rate, rainfall rate and barometric pressure.

\section{RESULTS AND DISCUSSION}

This research presents a series of experiments conducted at the Engineering Technical College of Al-Najaf, Al-Furat Al-Awsat Technical University as previously stated. The experimental results were obtained from a corrugated solar air collector under climatic conditions in Najaf city in the center Iraq over a period of 3 days (9-11 th January 2018) for three air mass flow value rates: $0.045,0.034$ and $0.023 \mathrm{~kg} / \mathrm{sec}$.

Figure 3-5 show the variations of the recorded solar irradiance intensity as well as the measured of absorber plate, glass cover, outlet, ambient temperatures at different air mass flow rates. The maximum amount of solar irradiance intensity over the 3 days measured 1017 , 981 and $1061 \mathrm{~W} / \mathrm{m}^{2}$ while the average solar irradiance intensity values were calculated to be 843,839 and 884 $\mathrm{W} / \mathrm{m}^{2}$ at the air mass flow rates of $0.045,0.034$ and 0.022 $\mathrm{kg} / \mathrm{sec}$, respectively. As observed from the experiments the maximum ambient temperature values were $18.5,19.9$ and $20.4^{\circ} \mathrm{C}$ while the average ambient temperature values were calculated to be $16.8,18.2$ and $19.1^{\circ} \mathrm{C}$ at the air mass flow rates of $0.045,0.034$ and $0.022 \mathrm{~kg} / \mathrm{sec}$, respectively. In addition, the maximum outlet temperatures were recorded as $40.3,44.7$ and $47.2^{\circ} \mathrm{C}$ while the average outlet temperature values calculated to be $36,39.2$ and $41.7^{\circ} \mathrm{C}$ at the air mass flow rates of $0.045,0.034$ and $0.023 \mathrm{~kg} / \mathrm{sec}$, respectively. It was also observed that the maximum values of the glass temperature were $37.6,39.1$ and $42.1^{\circ} \mathrm{C}$ while the average values of the glass temperatures were $33.4,34.9$ and $37.3^{\circ} \mathrm{C}$ at the air mass flow rates of 0.045 , 0.034 and $0.023 \mathrm{~kg} / \mathrm{sec}$, respectively. Furthermore, the maximum values of the plate temperature were $72.4,74.3$ and $79.1^{\circ} \mathrm{C}$ while the average values of the plate temperatures were calculated to be $67,68.2$ and $72.4^{\circ} \mathrm{C}$ at the air mass flow rates of $0.045,0.034$ and 0.023 $\mathrm{kg} / \mathrm{sec}$, respectively. It was expected that the plate temperature would decrease with an increasing air mass flow rate, thus, leading to a low heat loss coefficient. However, it is visible from the results that all temperatures increase with time as solar irradiance increases.

The difference between output and input temperatures $\Delta \mathrm{T}=\mathrm{T}_{\text {out }}-\mathrm{T}_{\text {in }}$ vs. hours of the day at different air mass

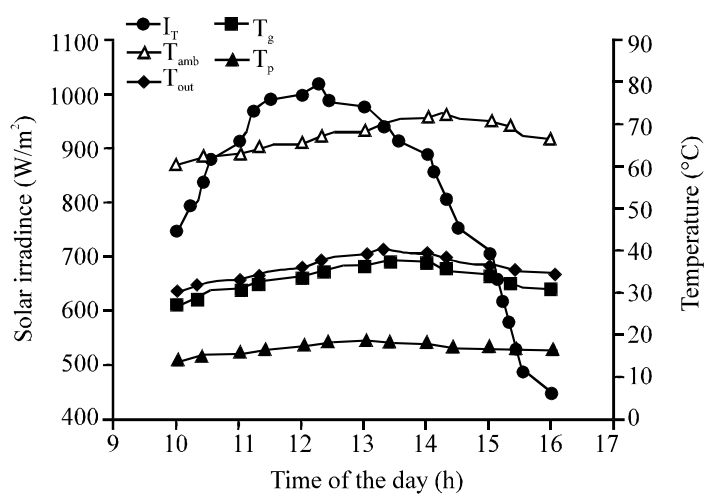

Fig. 3: Absorber, glass, outlet, ambient temperatures and solar irradiance vs. local time at air mass flow rate of $0.045 \mathrm{~kg} / \mathrm{sec}$

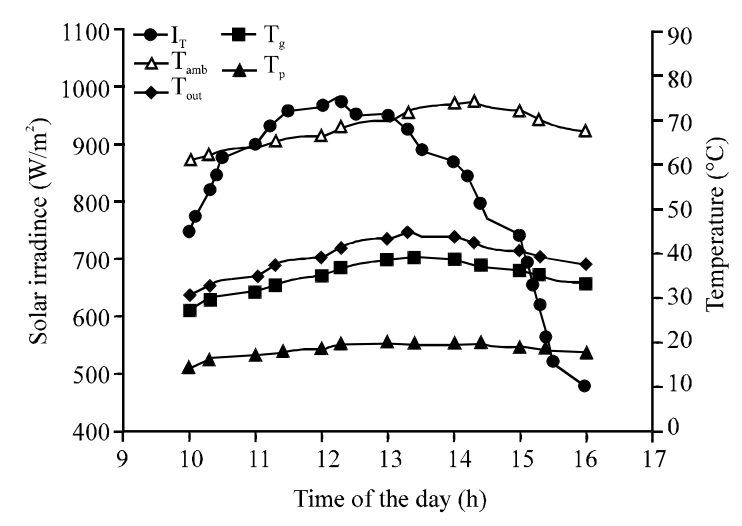

Fig. 4: Absorber, glass, outlet, ambient temperatures and solar irradiance vs. local time at air mass flow rate of $0.034 \mathrm{~kg} / \mathrm{sec}$

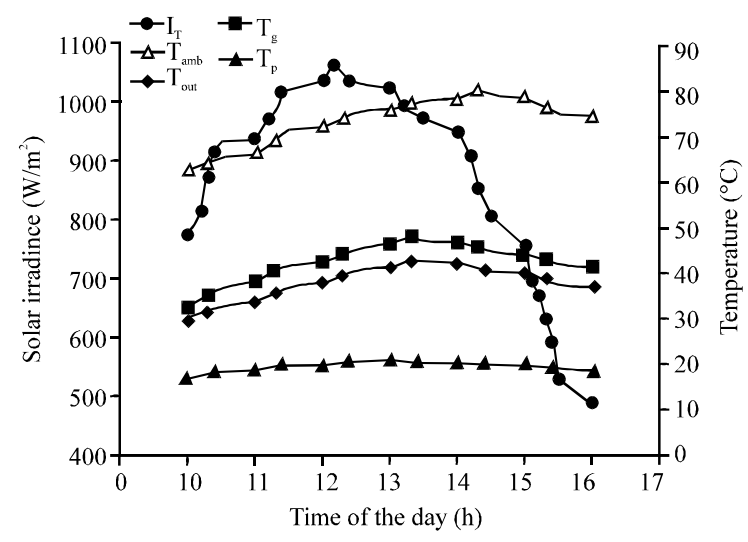

Fig. 5: Absorber, glass, outlet, ambient temperatures and solar irradiance vs. local time at air mass flow rate of $0.023 \mathrm{~kg} / \mathrm{sec}$

flow rates are presented in Fig. 6. The results reveal that the maximum temperature difference of the air were 


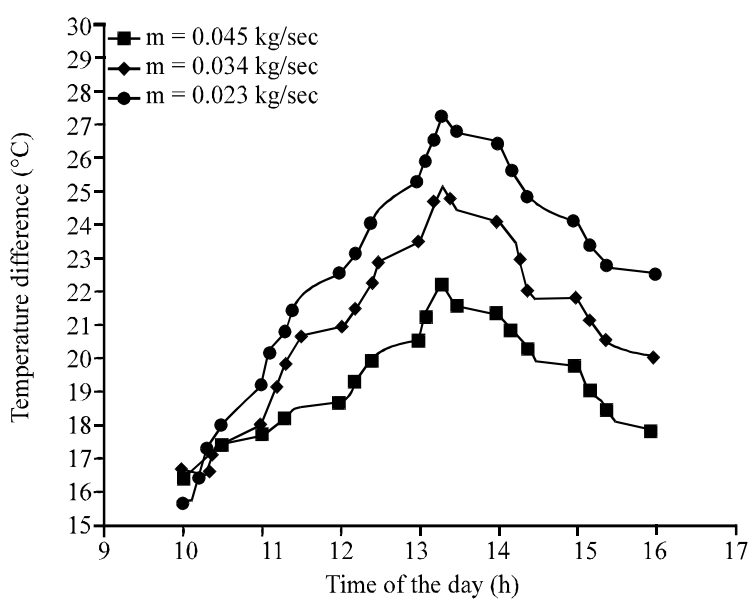

Fig. 6: A temperature difference of air versus local time at different air mass flow rates

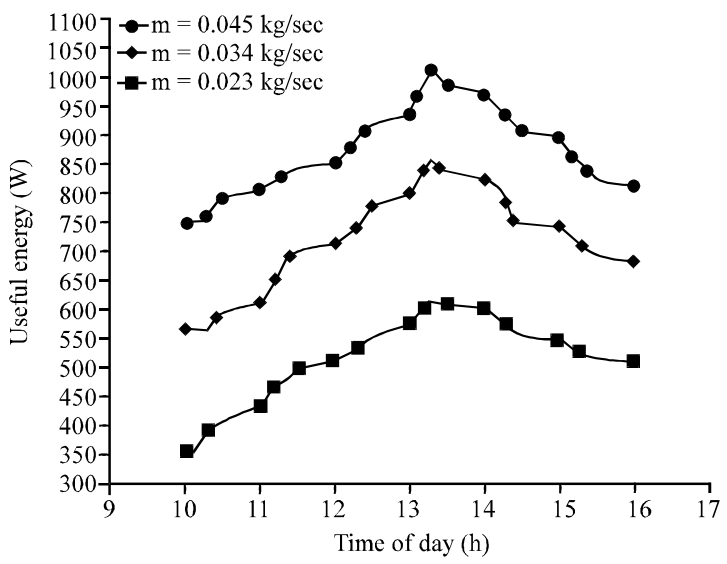

Fig. 7: A comparison of the measured useful energy of the collector versus local time at different air mass flow rates

$22.2,25.1$ and $27.2^{\circ} \mathrm{C}$ at the air mass flow rates were $0.045,0.034$ and $0.023 \mathrm{~kg} / \mathrm{sec}$, respectively. It is notable that the average values of the temperature difference were calculated to be $19.2,21$ and $22.6^{\circ} \mathrm{C}$ at the air mass flow rates of $0.045,0.034$ and $0.023 \mathrm{~kg} / \mathrm{sec}$, respectively.

Figure 7 shows the useful energy that was calculated vs. the standard local time during the experimental tests of the solar air collector at different air mass flow rates. It can be seen that the curves of useful energy and solar irradiance have the same direction. The results also show that useful energy gain increases when increasing the air mass flow rate. The values of the maximum useful energy were recorded to be 1009,855 and $618 \mathrm{~W}$ at the air mass flow rates of $0.045,0.034$ and $0.023 \mathrm{~kg} / \mathrm{sec}$, respectively. It also found that the average values of useful energy were 872,716 and $515 \mathrm{~W}$ at the air mass flow rates of 0.045 , 0.034 and $0.023 \mathrm{~kg} / \mathrm{sec}$, respectively.

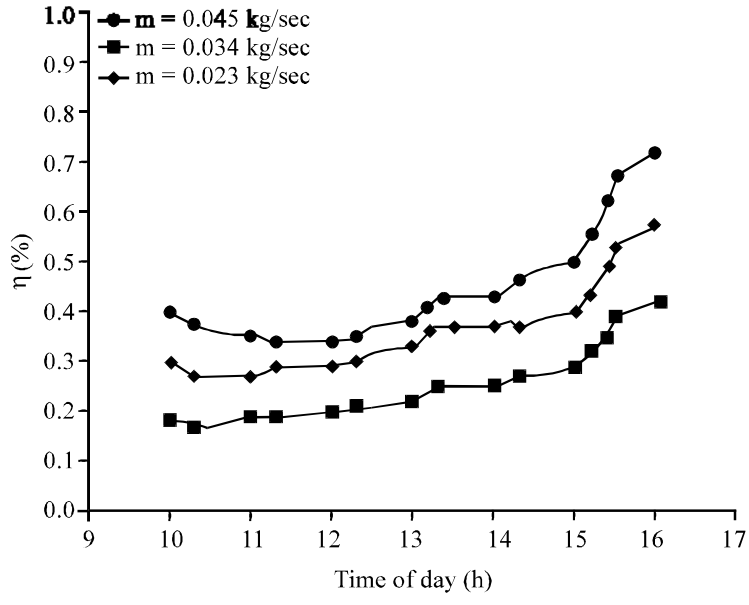

Fig. 8: A comparison of the calculated thermal efficiency of the collector vs. local time at different air mass flow rates

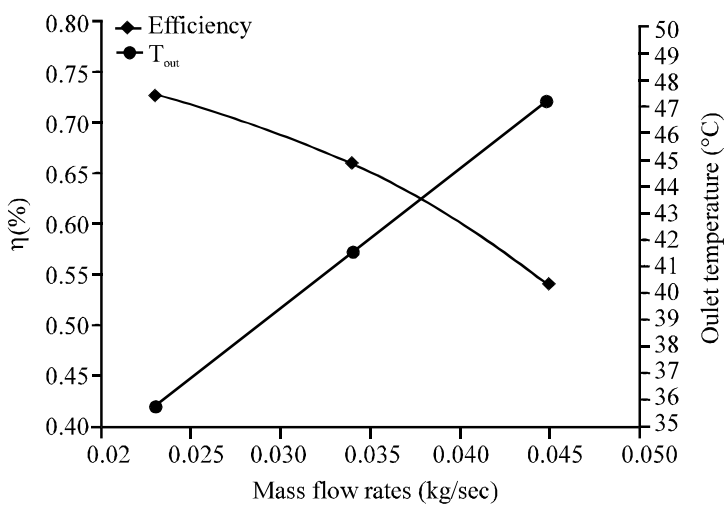

Fig. 9: Variation of thermal efficiency and outlet temperature at different air mass flow rates

The fluctuation in thermal efficiencies of the corrugated solar air collector vs. the standard local time of day at different air mass flow rates was presented in Fig. 8. The thermal efficiency values mostly continue to increase from morning to evening. The maximum values of thermal efficiency for the corrugated solar air collector were found to be 72,57 and $42 \%$ at the air mass flow rates of $0.045,0.034$ and $0.023 \mathrm{~kg} / \mathrm{sec}$, respectively.

Figure 9 shows the effect of variation of air mass flow rate on thermal efficiency and the outlet temperature for the corrugated solar air collector. It was found that the daily thermal efficiencies of the solar air collector increase as the mass flow rate increases. In contrast, the outlet temperature decreases. This may be because the plate temperature decreases when increasing the air mass flow rate, thus, leading to a decrease in the heat loss coefficient. 


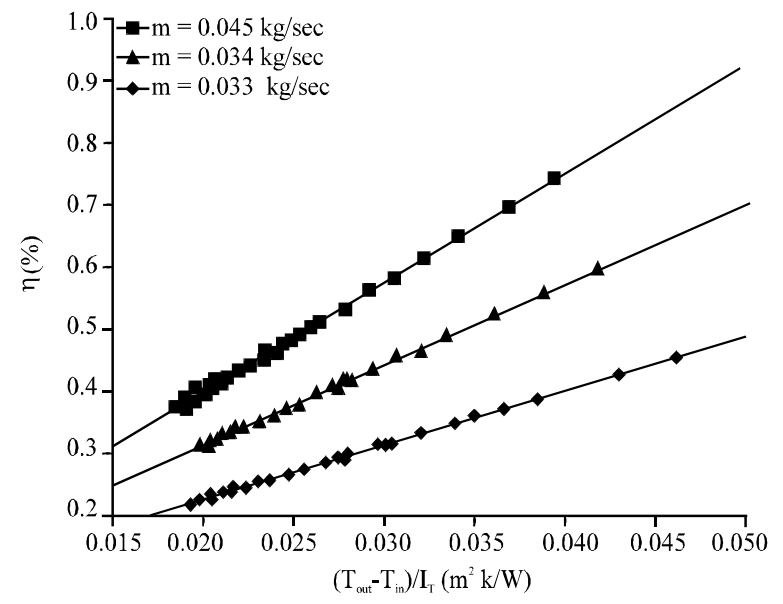

Fig. 10: Performance test of collector at different air mass flow rates

Three curves of thermal efficiency were plotted at different air mass flow rates. The objective was to study the direction of thermal efficiency curves at more air mass flow rates due to the fact that some applications for solar air collectors such as drying applications can take into consideration a wide range of operating temperatures and air mass flow rates. Figure 10 shows the efficiency curves which were obtained for the corrugated solar air collector at different air mass flow rates. It is apparent that the thermal efficiency increases with increasing the air mass flow rate.

\section{CONCLUSION}

An experimental investigation was conducted to assess the thermal performance evaluation of a backflow corrugated solar air collector under climatic conditions in Najaf city in middle Iraq. The suggested design of the "corrugated solar air collector" was found to enhance collector performance for several reasons. First, the excellent thermal conductivity of the aluminum led to an improvement in the heat transfer between the absorber plate surface and working fluid. Second, there were low thermal losses between the absorber plate surface and collector bottom due to good thermal insulation which led to high thermal efficiency. Third, the backflow of air inside the flow channel led to an obstruction in the air to gain more heat which caused an increase in the outlet air temperature. However, the present study recommends using a copper plate instead of an aluminum plate to enhance thermal conductivity and thus improve efficiency as well as increase the outlet air temperature, especially in applications that require a relatively high temperature such as drying applications. The air mass flow rate is one of the most important parameters affecting the performance of a solar air collector. Therefore, the thermal efficiency values increased from $42-72 \%$ while the outlet air temperature values decreased from $47.2-40.3^{\circ} \mathrm{C}$ at air mass flow rates of 0.023 and $0.045 \mathrm{~kg} / \mathrm{sec}$, respectively.

\section{NOMENCLATURE}

$$
\begin{aligned}
\mathrm{I}_{\mathrm{T}} & =\text { Solar irradiance intensity }\left(\mathrm{W} / \mathrm{m}^{2}\right) \\
\mathrm{h}_{\text {conv }} & =\text { Convection heat transfer }\left(\mathrm{W} / \mathrm{m}^{2}\right. \\
\mathrm{h}_{\text {rad }} & =\text { Radiation heat transfer }\left(\mathrm{W} / \mathrm{m}^{2} \mathrm{~K}\right) \\
\mathrm{h}_{\text {cond }} & =\text { Conduction heat transfer }\left(\mathrm{W} / \mathrm{m}^{2} \mathrm{~K}\right) \\
\mathrm{T} & =\text { Temperature }\left({ }^{\circ} \mathrm{C}\right) \\
\mathrm{t} & =\text { thickness }(\mathrm{mm}) \\
\mathrm{k} & =\text { Thermal conductivity }(\mathrm{W} / \mathrm{m} \mathrm{K}) \\
\mathrm{C}_{\mathrm{p}} & =\text { Specific heat capacity }(\mathrm{kJ} / \mathrm{kg} \mathrm{K}) \\
\mathrm{Q}_{\mathrm{u}} & =\text { Useful energy of collector }(\mathrm{W}) \\
\mathrm{m}_{\text {air }} & =\text { Air mass flow rate }(\mathrm{kg} / \mathrm{sec}) \\
\mathrm{A}_{\mathrm{c}} & =\text { Surface area of collector }\left(\mathrm{m}^{2}\right) \\
\mathrm{A}_{\text {ext }} & =\text { Cross section area of the duct }\left(\mathrm{m}^{2}\right) \\
1 & =\text { Absorber to glass distance }(\mathrm{m}) \\
\mathrm{W}_{\mathrm{v}} & =\text { Wind velocity (m/sec) } \\
\mathrm{V}_{\text {air }} & =\text { Air velocity }(\mathrm{m} / \mathrm{sec}) \\
\mathrm{D}_{\mathrm{H}} & =\text { Hydraulic diameter }(\mathrm{m}) \\
\mathrm{H}_{\mathrm{ch}} & =\text { Depth of air flow channel }(\mathrm{m}) \\
\mathrm{W}_{\mathrm{c}} & =\text { Width of air flow collector }(\mathrm{m}) \\
\mathrm{L}_{\mathrm{c}} & =\text { Length of the collector }(\mathrm{m}) \\
\mathrm{H}_{\mathrm{c}} & =\text { Height of the collector }(\mathrm{m}) \\
\mathrm{g} & =\text { Gravitational constant }\left(\mathrm{m}^{2} / \mathrm{sec}\right) \\
\mathrm{P}_{\mathrm{c}} & =\text { Perimeter of the collector }(\mathrm{m}) \\
\mathrm{N}_{\mathrm{u}} & =\text { Nusselt number (Dimensionless) } \\
\mathrm{R}_{\mathrm{a}} & =\text { Rayleigh number (Dimensionless) } \\
\mathrm{R}_{\mathrm{e}} & =\text { Reynolds number (Dimensionless) } \\
\mathrm{P}_{\mathrm{r}} & =\text { Prandtl number (Dimensionless) } \\
&
\end{aligned}
$$

\section{Greek symbols:}

$\rho=$ Density $\left(\mathrm{kJ} / \mathrm{m}^{3}\right)$

$\sigma=$ Stephan constant $\left(\mathrm{W} / \mathrm{m}^{2} \mathrm{~K}^{4}\right)$

$\varepsilon=$ Emissivity (Dimensionless)

$\eta_{\text {th }}=$ Thermal efficiency (\%)

$v=$ Kinetic viscosity $\left(\mathrm{m}^{2} / \mathrm{sec}\right)$

$\mu=$ Dynamic viscosity $(\mathrm{kg} / \mathrm{m} \mathrm{sec})$

$$
\begin{aligned}
& \text { Subscript: } \\
& \text { Out }=\text { Output } \\
& \begin{array}{ll}
\mathrm{in}=\text { Inlet } \\
\mathrm{amb}=\text { Ambient } \\
\mathrm{p} \quad=\text { plate } \\
\mathrm{g} \quad=\text { Glass } \\
\mathrm{m} \quad=\text { Mean } \\
\mathrm{g} . \mathrm{w}=\text { glass wool } \\
\beta^{\prime}=\text { Expansion coefficient }(1 / \mathrm{K}) \\
\beta \quad=\text { Tilt angle }\left(^{\circ}\right)
\end{array}
\end{aligned}
$$




\section{J. Eng. Applied Sci., 14 (Special Issue 3): 6006-6013, 2019}

\section{REFERENCES}

Aboghrara, A.M., B.T.H.T. Baharudin, M.A. Alghoul, N.M. Adam and A.A. Hairuddin et al., 2017. Performance analysis of solar air heater with jet impingement on corrugated absorber plate. Case Stud. Therm. Eng., 10: 111-120.

Al-Damook, A. and W.H. Khalil, 2017. Experimental evaluation of an unglazed solar air collector for building space heating in Iraq. Renewable Energy, 112: 498-509.

Al-Douri, Y. and F.M. Abed, 2016. Solar energy status in Iraq: Abundant or not-Steps forward. J. Renewable Sustainable Energy, Vol. 8. 10.1063/1.4947076

Arunachalam, U.P. and M. Edwin, 2017. Experimental investigations on thermal performance of solar air heater with different absorber plates. Intl. J. Heat Technol., 35: 393-397.

Chemkhi, S., F. Zagrouba and A. Bellagi, 2004. Drying of agricultural crops by solar energy. Desalin., 168: 101-109.

Duffie, J.A. and W.A. Beckman, 2013. Solar Engineering of Thermal Processes. 4th Edn., John Wiley and Sons, Hoboken, New Jersey, USA.,

El-Sebaii, A.A., S. Aboul-Enein, M.R.I. Ramadan, S.M. Shalaby and B. M. Moharram, 2011. Thermal performance investigation of double pass-finned plate solar air heater. Appl. Energy, 88: 1727-1739.

Hashe, V.T., 2017. Solar heating and cooling in buildings-how sustainable?. Procedia Manuf., 7: 92-97.

Hassan, H. and S. Abo-Elfadl, 2018. Experimental study on the performance of double pass and two inlet ports Solar Air Heater (SAH) at different configurations of the absorber plate. Renewable Energy, 116: 728-740.

Heydari, A. and M. Mesgarpour, 2018. Experimental analysis and numerical modeling of solar air heater with helical flow path. Sol. Energy, 162: 278-288.

Kabeel, A.E., A. Khalil, S.M. Shalaby and M.E. Zayed, 2016. Experimental investigation of thermal performance of flat and $\mathrm{V}$-corrugated plate solar air heaters with and without PCM as thermal energy storage. Energy Convers. Manage., 113: 264-272.

Kalogirou, S.A., 2014. Solar Energy Engineering Processes and Systems. 2nd Edn., Academic Press, Cambridge, Massachusetts, USA., ISBN:9780123972569, Pages: 840.

Karim, M.A. and M.N.A. Hawlader, 2006. Performance evaluation of a V-groove solar air collector for drying applications. Applied Thermal Eng., 26: 121-130.
Karim, M.A. and M.N.A. Hawlader, 2006. Performance investigation of flat plate, $\mathrm{V}$-corrugated and finned air collectors. Energy, 31: 452-470.

Karim, M.A., E. Perez and Z.M. Amin, 2014. Mathematical modelling of counter flow v-grove solar air collector. Renewable Energy, 67: 192-201.

Karwa, R. and V. Srivastava, 2013. Thermal performance of solar air heater having absorber plate with $\mathrm{V}$-down discrete rib roughness for space-heating applications. J. Renewable Energy, 2013: 1-13

Kiyan, M., E. Bingol, M. Melikoglu and A. Albostan, 2013. Modelling and simulation of a hybrid solar heating system for greenhouse applications using Matlab/Simulink. Energy Convers. Manage., 72: 147-155.

Lakshmi, D.V.N., A. Layek and P.M. Kumar, 2017. Performance analysis of trapezoidal corrugated solar air heater with sensible heat storage material. Energy Procedia, 109: 463-470.

Li, S., H. Wang, X. Meng and X. Wei, 2017. Comparative study on the performance of a new solar air collector with different surface shapes. Appl. Therm. Eng., 114: 639-644.

Lin, W., W. Gao and T. Liu, 2006. A parametric study on the thermal performance of cross-corrugated solar air collectors. Appl. Therm. Eng., 26: 1043-1053.

Mahmood, A.J., L.B.Y. Aldabbagh and F. Egelioglu, 2015. Investigation of single and double pass solar air heater with transverse fins and a package wire mesh layer. Energy Convers. Manage., 89: 599-607.

Mohammad, A.T., 2017. Design and analysis of solar space heating system in Iraq. Intl. J. Therm. Environ. Eng., 15: 51-56.

Rajaseenivasan, T., S.R. Prasanth, M.S. Antony and K. Srithar, 2017. Experimental investigation on the performance of an impinging jet solar air heater. Alexandria Eng. J., 56: 63-69.

Saxena, A., G. Srivastava and V. Tirth, 2015. Design and thermal performance evaluation of a novel solar air heater. Renewable Energy, 77: 501-511.

Yang, M., P. Wang, X. Yang and M. Shan, 2012. Experimental analysis on thermal performance of a solar air collector with a single pass. Build. Environ., 56: $361-369$.

Yeh, H.M. and T.T. Lin, 1996. Efficiency improvement of flat-plate solar air heaters. Energy, 21: 435-443. 